\title{
PERFORMANCE OF MAIZE CROSSES UNDER LATE PLANTING CONDITION
}

\author{
M. E. Ibrahim ${ }^{(1)}$, O.A.M. Ali(1), M.A. Elbatal(2) and Rahma M. Elhelw(2) \\ (1) Crop Sci. Dept., Faculty of Agric., Menoufia Univ., Egypt. \\ (2) Crop physiology Dept., Field Crop Research Institute, ARC, Egypt.
}

Received: Dec. 28 , 2019

Accepted: Dec. 25, 2019

\begin{abstract}
A field experiment was carried out to evaluate the performance of seven white maize hybrids under late planting condition with respect to yield and grain quality during the two successive seasons of 2017 and 2018. The experimental design was laid out using randomized complete block design with four replicates. Maize hybrids were significantly differed in all traits studied in both seasons, except grain oil percentage. The variety S.C 128 exhibited the highest days to maturity, while the lowest ones was T.W.C 321 in both seasons as compared with other tested hybrids. The variety T.W.C 321 significantly surpassed other tested hybrids in mean values of grain yield /fed and relative grain yielding ability, while T.W.C 324 and T.W.C 329 gave the lowest mean values in both seasons. Concerning grain quality, S.C 131 and S.C 2031 recorded the highest mean values of oil yield/fed, Meanwhile, T.W.C 321 and S.C 2031 surpassed the other hybrids in mean values of protein percentage and protein yield/fed in the both seasons. It could be summarized that the best hybrid was T.W.C 321 when planting maize in late sowing, where it produced grain yield more than other S.C 131, S.C 2031, S.C 10, S.C 128, T.W.C 324 and T.W.C 329 hybrids by 2.74, 3.08, 4.85, 4.89, 21.40 and 24.96\%, respectively as an average of both seasons.
\end{abstract}

Key words: Zea mays, Hybrids, Yielding ability and grain quality.

\section{INTRODUCTION}

Maize is one of the most important cereal crops, where it is one of the important foods, green forage and industrial crops of the world. In the developing countries, maize is a major source of income to farmers. It ranks the third cereal crop after wheat and rice. In Egypt, the local production of maize did not satisfy the local consumption (FAO, 2017). Great attention has been paid to increase maize production. The horizontal expansion is only possible through growing maize in the new reclaimed lands that requires high costs. The vertical expansion could be achieve via growing high yielding varieties that have more tolerance to biotic and abiotic stresses. Low yield of maize is due to many constraints but among them, planting in late date was exposing plants to high temperature during pollen fertilization and grain filling period (Ali et al., 2015). Climatic change is a growing global problem challenging sustainable development and placing a constraint on producing enough food to meet increasing food requirements.

Maize genotypes are significantly differed with respect to yield and grain quality (El-Shahed et al., 2013 and Koca and Canavar, 2014). Many investigators found high variation among maize varieties in their grain yield in favor of single cross (S.C) varieties as mentioned by Ali and Mohammed (2015) and Yasin (2016), Other investigators mentioned that three way crosses (T.W.C) surpassed other single ones (Abdel-Maksoud and Sarhan, 2008). Breeders of maize seek to enhance genotypes yield and adapt to climatic changes which could give high 
M. E. Ibrahim, et al.,

yielding under heat stress at late planting condition.

Therefore, the aim of this study was to evaluate the performance of some single and three way crosses grown under late planting condition.

\section{MATERIALS AND METHODS}

\section{Design and experimental procedures}

A field experiment was carried out at the Experimental Farm of Agricultural Research Center (A.R.C.), Giza, Egypt, during the two successive seasons of 2017 and 2018. The aim of this study was evaluation the performance of seven white maize hybrids (S.C 10, S.C 128, S.C 131, S.C 2031, T.W.C 321, T.W.C 324 and T.W.C 329) under late planting condition (mid-June) with respect to yield and grain quality. The tested hybrids were obtained annually from Agricultural Research Center, Egypt except S.C 2031 which produced by Hi-Tech Co. The experimental design was laid out using randomized complete block design with four replicates.

\section{Site description}

Some chemical and mechanical analysis of the experimental soil (0-30 $\mathrm{cm})$ were determined according to methods described by Jackson (1973) and Chapman and Pratt (1978), and data represented in Table (1). Detailed climatic data during the growing periods were obtained from Central Laboratory for Agricultural Climate as shown in Table (2).

\section{Crop management}

The experimental site was ploughed twice, harrowed and leveled. The preceding winter crop in the two seasons was faba bean. Plot area was $12.60 \mathrm{~m}^{2}$ contains six ridges of $3 \mathrm{~m}$ long and $70 \mathrm{~cm}$ apart. Calcium super phosphate $(15.5 \%$ $\mathrm{P}_{2} \mathrm{O}_{5}$ ) was applied at a rate of $150 \mathrm{~kg} / \mathrm{fed}$ during soil preparation. Maize grains were planted on mid-June with spacing $25 \mathrm{~cm}$ between hills in both seasons. Maize plants were thinned to one plant $I$ hill (240000 plants/fed) before the first irrigation. Nitrogen fertilizer was applied at a rate of $120 \mathrm{~kg} \mathrm{~N} / \mathrm{fed}$ in the form of urea $(46.5 \% \mathrm{~N})$ in two equal doses, the first dose was applied directly before the first irrigation and the second one was added before the second irrigation. The first irrigation was applied at 21 days after sowing (DAS) and the following irrigations were applied every 12 days interval during the two growing seasons. The other agricultural practices were applied according to the recommendations of Agriculture and Land Reclamation Ministry.

\section{Plant measurements \\ Yield traits:}

Days to maturity, grain yield /fed and relative grain yielding ability traits were determined. Grain yield of inner two ridges in each plot were harvested and then converted to kg/fed. Relative grain yielding ability (RGYA) was calculated from the following formula:

RGYA $=\frac{\text { Grain yield }(\mathrm{kg} / \mathrm{fed})}{\text { Days to maturity }}(\mathbf{k g}$ grain/day)

Table (1): Some physical and chemical properties of the experimental sites.

\begin{tabular}{|l|c|l|c|c|c|c|c|}
\hline Seasons & Soil texture & \multirow{2}{*}{$\begin{array}{l}\text { Organic } \\
\text { matter (\%) }\end{array}$} & $\mathrm{pH}$ & \multirow{2}{*}{$\begin{array}{c}\text { Ec } \\
(\mathrm{ds} / \mathrm{m})\end{array}$} & \multicolumn{3}{|c|}{ Available nutrients (ppm) } \\
\cline { 6 - 8 } & & & & $\mathrm{N}$ & $\mathrm{P}$ & $\mathrm{K}$ \\
\hline 2017 & Clay loam & 1.64 & 7.6 & 0.62 & 39 & 8.9 & 486 \\
\hline 2018 & Clay loam & 1.58 & 7.4 & 0.68 & 42 & 9.2 & 481 \\
\hline
\end{tabular}


Performance of maize crosses under late planting condition

Table (2): Average weekly temperature during the growth period in both growing seasons.

\begin{tabular}{|c|c|c|c|c|c|c|c|}
\hline \multicolumn{2}{|c|}{ Season } & \multirow{2}{*}{\multicolumn{3}{|c|}{$\frac{2017}{\text { Temperature (Co) }}$}} & \multirow{2}{*}{\multicolumn{3}{|c|}{$\frac{2018}{\text { Temperature (Co) }}$}} \\
\hline \multirow{2}{*}{ Month } & \multirow{2}{*}{ Week } & & & & & & \\
\hline & & Max. & Min. & Mean & Max. & Min. & Mean \\
\hline \multirow{2}{*}{ June } & $3^{\text {rd }}$ week & 36.48 & 23.14 & 29.81 & 37.83 & 24.34 & 31.09 \\
\hline & $4^{\text {th }}$ week & 36.90 & 20.18 & 28.54 & 37.13 & 24.14 & 30.64 \\
\hline \multirow[t]{4}{*}{ July } & $1^{\text {st }}$ week & 38.69 & 24.91 & 31.80 & 33.71 & 23.19 & 28.45 \\
\hline & $2^{\text {nd }}$ week & 38.71 & 23.81 & 31.26 & 37.69 & 24.66 & 31.18 \\
\hline & $3^{\text {rd }}$ week & 38.30 & 24.88 & 31.59 & 37.86 & 24.51 & 31.19 \\
\hline & $4^{\text {th }}$ week & 37.32 & 24.32 & 30.82 & 38.41 & 24.97 & 31.69 \\
\hline \multirow[t]{4}{*}{ August } & $1^{\text {st }}$ week & 37.86 & 24.44 & 31.15 & 32.40 & 21.65 & 27.03 \\
\hline & $2^{\text {nd }}$ week & 37.34 & 25.99 & 31.67 & 32.58 & 21.60 & 27.09 \\
\hline & $3^{\text {rd }}$ week & 37.29 & 24.45 & 30.87 & 36.40 & 25.05 & 30.73 \\
\hline & $4^{\text {th }}$ week & 36.18 & 23.58 & 29.88 & 36.62 & 24.93 & 30.78 \\
\hline \multirow[t]{4}{*}{ September } & $1^{\text {st }}$ week & 35.54 & 22.40 & 28.97 & 28.21 & 21.89 & 25.05 \\
\hline & $2^{\text {nd }}$ week & 36.40 & 22.59 & 29.50 & 31.23 & 20.96 & 26.10 \\
\hline & $3^{\text {rd }}$ week & 35.68 & 22.79 & 29.24 & 34.70 & 23.51 & 29.11 \\
\hline & $4^{\text {th }}$ week & 32.35 & 21.09 & 26.72 & 34.83 & 24.08 & 29.46 \\
\hline October & $1^{\text {st }}$ week & 33.67 & 19.69 & 26.68 & 33.03 & 23.08 & 28.06 \\
\hline
\end{tabular}

\section{Grain quality:}

At maturity, grain samples were dried in air-oven at $70^{\circ} \mathrm{C}$ to constant weight before grinding with a mill to pass through a $0.5 \mathrm{~mm}$ sieve. The samples were chemically analyzed to determine their contents (oil and protein) and their yields as follows:

- Protein (\%): nitrogen \% was determined according to AOAC (2007) and protein was calculated by multiplying the $\mathrm{N}$ by factor 5.75 .

- Protein yield (kg/fed) was determined by multiplying grain yield/fed by protein percentage.
- Oil (\%) was determined according to AOAC (2007) using soxhlet apparatus using petroleum ether as a solvent.

- Oil yield (kg/fed) was determined by multiplying grain yield/fed by oil percentage.

\section{Statistical analysis}

The analysis of variance was carried out according to the procedure described by Snedecor and Cochran (1980). Duncan's multiple range test (Duncan, 1955) was used to compare between the treatments mean at $5 \%$ probability. Statistical analysis was done using the 
M. E. Ibrahim, et al.,

CoStat package program, version 6.311 (Cohort software, USA).

\section{RESULTS AND DISCUSSION}

\section{A. Yield traits:}

Data presented in Table (3) indicated that the differences among tested hybrids were significant for days to maturity, grain yield/fed and relative grain yielding ability in both seasons. Results revealed that days to maturity ranged from 100.75 to 107.75 in the first season and from 102.50 to 111.25 in the second one. The variety S.C 128 exhibited the highest days to physiological maturity, while the lowest ones obtained by T.W.C 321 and T.W.C 329 in both seasons. These differences may be due to the genetic differences between the tested hybrids. In this concern, other researchers noted the variation among maize hybrids in days to maturity as mentioned by Dawadi and Sah (2012), Prasad et al. (2017) and Belay and Patil (2018).

Table (3): Effect of varietal differences on maturity, grain yield and relative grain yielding ability of maize during 2017 and 2018 seasons.

\begin{tabular}{|c|c|c|c|}
\hline Hybrids & Days to maturity & $\begin{array}{l}\text { Grain yield } \\
\text { (kg/fed) }\end{array}$ & $\begin{array}{c}\text { Relative grain } \\
\text { yielding ability } \\
\text { (kg/day) }\end{array}$ \\
\hline \multicolumn{4}{|c|}{2017 season } \\
\hline S.C 10 & $106.75 \mathrm{a}$ & $3402.50 \mathrm{~b}$ & $31.87 \mathrm{~b}$ \\
\hline S.C 128 & 107.75 a & 3367.25 b & $31.24 \mathrm{~b}$ \\
\hline S.C 131 & $104.75 \mathrm{~b}$ & $3458.00 a b$ & $33.01 \mathrm{~b}$ \\
\hline S.C 2031 & $104.50 \mathrm{~b}$ & $3443.50 a b$ & $32.96 \mathrm{~b}$ \\
\hline T.W.C 321 & $100.75 \mathrm{c}$ & $3564.25 \mathrm{a}$ & $35.37 \mathrm{a}$ \\
\hline T.W.C 324 & $102.00 \mathrm{c}$ & $2849.00 \mathrm{c}$ & $27.93 \mathrm{c}$ \\
\hline T.W.C 329 & $101.00 \mathrm{c}$ & $2802.25 \mathrm{C}$ & $27.75 \mathrm{c}$ \\
\hline \multicolumn{4}{|c|}{2018 season } \\
\hline S.C 10 & $110.25 \mathrm{~b}$ & $3141.00 \mathrm{~b}$ & $28.50 \mathrm{bc}$ \\
\hline S.C 128 & $111.25 \mathrm{a}$ & $3173.75 a b$ & $28.53 \mathrm{bc}$ \\
\hline S.C 131 & $109.00 \mathrm{c}$ & $3219.50 \mathrm{ab}$ & $29.54 \mathrm{~b}$ \\
\hline S.C 2031 & $107.00 \mathrm{~d}$ & $3212.25 a b$ & $30.02 \mathrm{~b}$ \\
\hline T.W.C 321 & $102.50 \mathrm{f}$ & $3296.50 \mathrm{a}$ & $32.16 \mathrm{a}$ \\
\hline T.W.C 324 & $103.75 \mathrm{e}$ & $2802.25 \mathrm{c}$ & $27.02 \mathrm{~cd}$ \\
\hline T.W.C 329 & $103.00 \mathrm{f}$ & 2688.25 c & $26.10 \mathrm{~d}$ \\
\hline
\end{tabular}


Maize hybrids exhibited significant differences in their grain yield/fed in both seasons. The variety T.W.C 321 hybrid significantly surpassed other tested crosses without significant difference among S.C 131 and S.C 2031 in the first season and S.C 131, S.C 2031 and S.C 128 in the second one. However, the lowest values were recorded by T.W.C 329 and T.W.C 324 hybrids. Planting T.W.C 321 hybrid in late sowing produced grain yield more than S.C 131, S.C 2031, S.C 10, S.C 128, T.W.C 324 and T.W.C 329 hybrids by $2.74,3.08,4.85,4.89,21.40$ and $24.96 \%$ as an average of both seasons. Differences among hybrids can be attributable to changes in heat tolerance (Table 2) and light interception and utilization. When maize hybrids more tolerance to grown under late condition (heat stress), plants could have better opportunity to produce more metabolite contents as well as increased translocation and accumulation of metabolites through grains and consequently gave the maximum values of grain yield. Many authors found significant differences among maize genotypes in grain yield/unit area in favor of T.W.C 310 (Abdel-Maksoud and Sarhan, 2008), S.C 3084 (El-Gizawy and Salem, 2010), S.C 704 (Dahmardeh, 2012), S.C 10 (El-Shahed et al., 2013) and S.C 2031 (Ali and Mohammed, 2015).

It could be noticed that planting T.W.C 321 was superior to the other tested hybrids in increasing relative grain yielding ability in both seasons (Table 3). On the other hand, T.W.C 329 and T.W.C 324 hybrids recorded the lowest ones. This result could be explained on the fact that in case of variety that required low days to maturity and high grain yield produced resulted in high relative grain yielding ability.

\section{B. Grain quality:}

It is clear from the obtained data in Table (4) that there were significant differences in protein percentage as well as oil and protein yields/fed in both seasons. However, no significant differences could be detected among the tested maize hybrids in oil percentage in both seasons. The hybrid S.C 131 produced the highest values of oil yield, while T.W.C 329 hybrid recorded the lowest one. These results were true in the two seasons. However, there were no statistically significant differences between S.C 131 and each of T.W.C 321, S.C 2031, S.C 128 and S.C 10 in both seasons. It seemed that the large oil yield/fed may be resulted from the increase in grain yield $I$ fed and oil percentage by such hybrids. In this respect, Koca and Canavar (2014) mentioned that there were differences between maize cultivars in grain oil content.

The grain protein percentage and protein yield Ifed of maize hybrids are presented in Table (4). In both seasons, there were significant differences in both traits. Generally, it can be noted that the highest protein percentage and its yield were obtained by planting the variety T.W.C 321 followed by S.C 2031 without significant difference between them. On the other hand, T.W.C 324 was the inferior hybrid for protein percentage and protein yield. The superiority of these hybrids in protein percentage may be attributed that has more ability to transport enough absorbed nitrogen to grains more than that of the inferior hybrids under the late sowing condition. Concerning protein yield, the most probable explanation for this result is that well agrees with the concomitant increase in the grain yield/fed and protein percentage. The genotype differences in grain protein were previously reported in favor of NK-Arma (Koca and Canavar, 2014), T.W.C 352 (El-Shahed et al., 2013) and S.C 168 (Al-Sharkawy et al., 2016). 
M. E. Ibrahim, et al.,

Table (4): Grain oil and protein percentages and their yields of maize hybrids in late planting during 2017 and 2018 seasons.

\begin{tabular}{|c|c|c|c|c|}
\hline Hybrids & Oil \% & $\begin{array}{l}\text { Oil yield } \\
\text { (kg/fed) }\end{array}$ & Protein \% & $\begin{array}{l}\text { Protein yield } \\
\text { (kg/fed) }\end{array}$ \\
\hline \multicolumn{5}{|c|}{2017 season } \\
\hline S.C 10 & $4.23 \mathrm{a}$ & $143.64 a b$ & $10.43 \mathrm{ab}$ & $354.72 \mathrm{abc}$ \\
\hline S.C 128 & $4.36 \mathrm{a}$ & $146.30 \mathrm{ab}$ & $9.98 \mathrm{bc}$ & $335.86 \mathrm{c}$ \\
\hline S.C 131 & $4.59 \mathrm{a}$ & $158.95 \mathrm{a}$ & $10.03 \mathrm{bc}$ & $346.83 \mathrm{bc}$ \\
\hline S.C 2031 & $4.29 \mathrm{a}$ & $148.03 a b$ & $10.77 \mathrm{a}$ & $371.16 a b$ \\
\hline T.W.C 321 & $4.06 \mathrm{a}$ & $144.67 \mathrm{ab}$ & $10.71 \mathrm{a}$ & $381.39 a$ \\
\hline T.W.C 324 & $4.32 \mathrm{a}$ & $123.48 \mathrm{bc}$ & $9.80 \mathrm{c}$ & $279.17 \mathrm{~d}$ \\
\hline T.W.C 329 & $4.00 \mathrm{a}$ & $112.08 \mathrm{c}$ & $10.66 \mathrm{a}$ & $298.48 d$ \\
\hline \multicolumn{5}{|c|}{2018 season } \\
\hline S.C 10 & $4.21 \mathrm{a}$ & $132.21 \mathrm{ab}$ & $10.04 \mathrm{ab}$ & $315.31 \mathrm{a}$ \\
\hline S.C 128 & $4.67 \mathrm{a}$ & $148.21 \mathrm{a}$ & $9.92 \mathrm{~b}$ & $314.78 \mathrm{a}$ \\
\hline S.C 131 & $4.84 \mathrm{a}$ & $155.42 \mathrm{a}$ & $10.16 \mathrm{ab}$ & $327.16 \mathrm{a}$ \\
\hline S.C 2031 & $4.68 \mathrm{a}$ & $150.57 \mathrm{a}$ & $10.29 \mathrm{a}$ & $330.44 a$ \\
\hline T.W.C 321 & $4.54 \mathrm{a}$ & $150.00 \mathrm{a}$ & $10.21 \mathrm{ab}$ & $336.58 \mathrm{a}$ \\
\hline T.W.C 324 & $4.60 \mathrm{a}$ & $128.66 \mathrm{ab}$ & $9.24 \mathrm{c}$ & $258.94 \mathrm{~b}$ \\
\hline T.W.C 329 & $4.39 \mathrm{a}$ & $117.84 \mathrm{~b}$ & $9.98 a b$ & $268.23 \mathrm{~b}$ \\
\hline
\end{tabular}

\section{Conclusion:}

Maize hybrids were significantly differed in their yield and grain quality. It could be summarized that the best hybrid performance was the hybrid T.W.C 321 when planting maize in late sowing, where it produced grain yield more than other S.C 131, S.C 2031, S.C 10, S.C 128, T.W.C 324 and T.W.C 329 hybrids by 2.74, $3.08,4.85,4.89,21.40$ and $24.96 \%$ as an average of both seasons.

\section{REFERENCES}

Abdel-Maksoud, M.F and A.A. Sarhan (2008). Response of some maize hybrids to bio and chemical nitrogen fertilization. Zagazig J. Agric. Res., 35 (3): 497-515.

Ali, O.A.M. and A.S.H. Mohammed (2015). Performance evaluation of gated pipes technique for improving surface irrigation efficiency in maize hybrids. Agricultural Sciences, 6, 550-570; http://dx.doi.org/10.4236/as.2015.6505 $\underline{5}$

Ali, S.I.; A. Jan, M. Din and M. Habibullah (2015). Yield response of maize (Zea mays L.) hybrids sown on various dates during kharif in PeshawarPakistan. J. Environ. Earth Sci. 5: 1317. 
Al-Sharkawy, N.A.T., S.A.I. Ghanem, E.H.M. Fayed and M.M.A. Osman (2016). Yield and its attributes of two maize cultivars and associated weeds as affected by some weed control methods and nitrogen fertilizer levels. Zagazig J. Agric. Res., 43(5): 14751488.

AOAC (2007). Official Methods of Analysis. $18^{\text {th }}$ Ed. Association of Official Analytical Chemists, Inc., Gaithersburg, MD, http://www. eoma. aoac.orgl.

Belay, A.T. and R.H. Patil (2018). Response of maize hybrids to sowing dates in northern trazitional zone of Karnataka. Int. J. Pure App. Biosci., 6 (1): 71-84.

Chapman, H.D. and P.F. Pratt (1978). Methods of Analysis for Soils, Plants and Water, Division of Agricultural Sciences, University of California.

Dahmardeh, M. (2012). Effects of sowing date on the growth and yield of maize cultivars (Zea mays L.) and the growth temperature requirements. African Journal of Biotechnology, 11 (61): 12450-12453.

Dawadi, D.R. and S.K. Sah (2012). Growth and yield of maize (Zea mays L.) in relation to planting density and nitrogen levels during winter season in Nepal. Tropical Agricultural Research, 23 (3): 218-227.

Duncan, D.B. (1955). Multiple range and multiple $F$ tests. International Biometric Society Biometrics, 11 (1): 1-42.
El-Gizawy, N.Kh.B. and H.M. Salem (2010). Influence of nitrogen sources on yield and its components of some varieties. World $\mathrm{J}$. of Agricultural Sciences, 6 (2): 218-223.

El-Shahed, H.M., M.E. Saleh, S.A. Mowafy and M.M.A. Osman (2013). Effect of planting density and skipping irrigation at certain growth stages on yield potentiality of some maize hybrids. Zagazig J. Agric. Res., 40 (4): 617-646.

FAO, (2017). FAOSTAT, http://www.fao.org/faostat/en/\#data/Q C

Jackson, M.L. (1973). "Soil Chemical Analysis". Prentice-Hall of India Private Limited, New Delhi, 25-214.

Koca, Y.O. and O. Canavar (2014). The effect of sowing date on yield and yield components and seed quality of corn (Zea mays L.). Scientific Papers. Series A. Agronomy, LVII, 227-231.

Prasad, G., M. Chand, P. Kumar and R.S. Rinwa (2017). Performance of maize (Zea mays L.) hybrids with respect to growth parameters and phonological stages under different sowing dates in kharif season. Int. J. Curr. Microbiol. App. Sci., 6 (10): 5079-5087.

Snedecor, G.W. and W.G. Cochran (1980). Statistical Methods, $7^{\text {th }}$ Ed. The lowa State Univ. Press, Ames. lowa, USA.

Yasin, M.A.T. (2016). Response of two yellow maize hybrids to irrigation intervals and nitrogen fertilizer levels. J. Plant Production, Mansoura Univ., 7(12): 1465 -1472. 


\section{كفاءة هجن الذرة الثامية تحت ظروف الزراعة المتأخرة}

محمود الاسوقى إبراهيم(")، أسامه على محمد على(')، مسعد عبد العاطى البطل(؟)، رحمة ماهر الحلو (r)

(1) قسم المحاصيل - كلية الزراعة - جامعة المنوفية - مصر

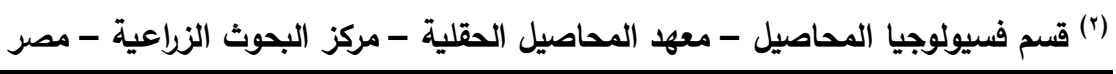

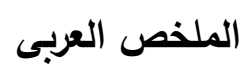

أجريت تجربة حقلية بهذف تقييم محصول وجودة حبوب بعض هجن الذرة الثامية البيضاء للنمو تحت ظروف الزراعة

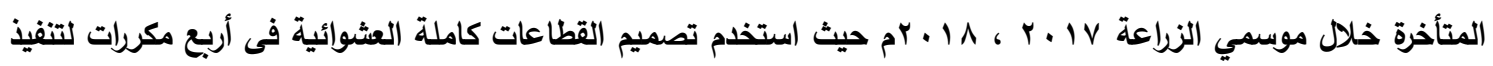

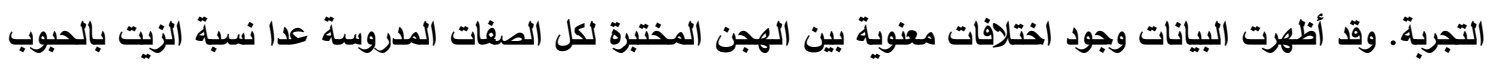

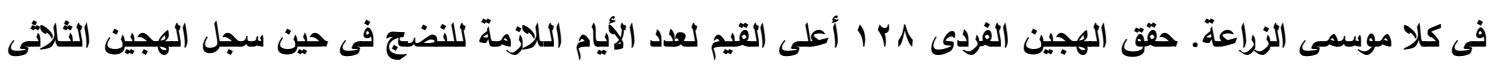

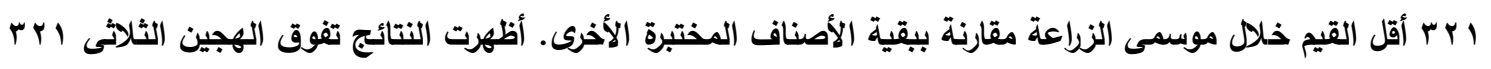

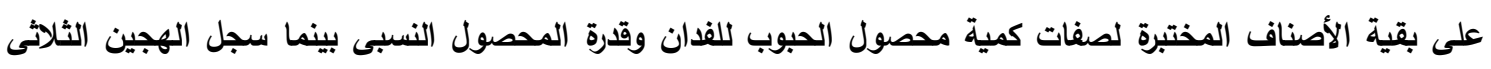

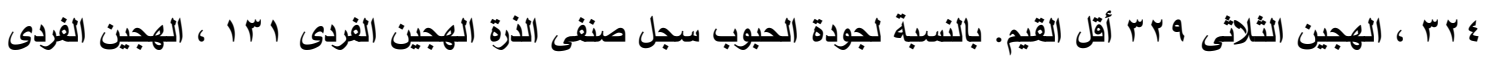

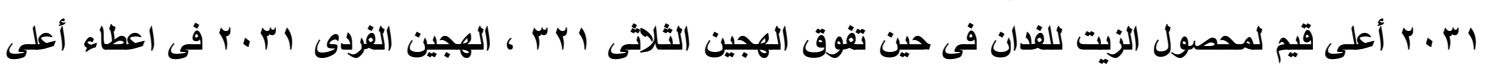

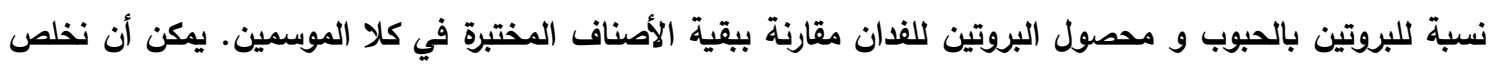

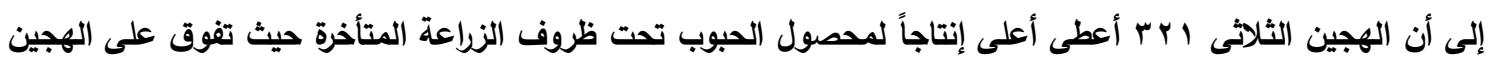

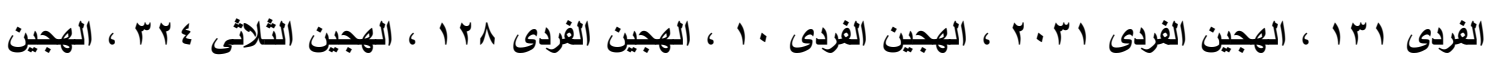

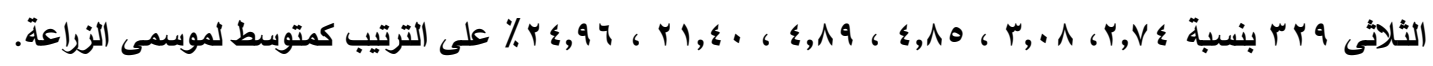

السادة المحكمين

مركز البحوث الزراعية - الجيزة أ.د/ فاطمة عبدالمنصــف

أ.د/ شعبان أحمد الثمارقة كلية الزراعة - جامعة المنوفية 